\title{
Analisis Kemampuan Pemecahan Masalah Matematika Berdasarkan Teori Polya Pada Siswa SD Kelas VI Kabupaten Manokwari
}

\author{
Nahrun Najib Siregar ${ }^{*}$, Firmansyah ${ }^{2}$ \\ ${ }^{1}$ Universitas Papua, Manokwari, Indonesia \\ 2 Universitas Papua, Manokwari, Indonesia \\ *Corresponding author: n.siregar@unipa.ac.id
}

\begin{abstract}
One of the goals of learning mathematics is to develop problem-solving skills. This study aims to analyze the ability to solve mathematical problems based on the theory of Polya in Class VI Elementary School Students in Manokwari Regency. The research method used by researchers is qualitative research with a descriptive approach. This research procedure consists of 5 stages, namely 1) research preparation, 2) data collection, 3) data analysis, 4) data presentation and drawing conclusions. 5) Preparation of Reports and Publications. The output of this research is an accredited national journal publication. This research is a qualitative research. Data collection techniques consisted of written tests, interviews and documentation. The data were analyzed qualitatively. The results of this study were 1) Students in the high category have the ability to understand problems, plan problem solving, implement plans, review very well. 2) Students in the medium category have the ability to understand problems and plan excellent problem solving. In addition, students in the medium category also have the ability to implement plans that are quite good, but have poor reviewing abilities. 3) Students in the low category have the ability to understand problems and plan problems quite well, but have the ability to plan problem solving and carry out poor plans. In addition, students in the low category do not take the stage of reviewing answers.
\end{abstract}

Keywords: mathematics; polya theory; problem solving ability

\begin{abstract}
ABSTRAK
Salah satu tujuan pembelajaran matematika adalah mengembangkan kemampuan pemecahan masalah. Penelitian ini bertujuan untuk menganalisis kemampuan pemecahan masalah matematika berdasarkan teori Polya pada Siswa SD Kelas VI Kabupaten Manokwari. Metode penelitian yang digunakan oleh peneliti merupakan penelitian kualitatif dengan pendekatan deskriptif. Prosedur penelitian ini terdiri dari 5 tahap yaitu 1) Persiapan penelitian, 2) Pengumpulan data, 3) Analisis data, 4) Penyajian data dan penarikan kesimpulan. 5) Pembuatan Laporan dan Publikasi. Luaran pada penelitian ini adalah publikasi jurnal nasional terakreditasi. Penelitian ini merupakan penelitian kualitatif. Tehnik pengumpulan data terdiri dari Tes tertulis, Wawancara dan dokumentasi. Data dianalisis secara kualitatif .Hasil penelitian ini adalah 1) Siswa pada kategori tinggi memiliki kemampuan untuk memahami masalah, merencanakan pemecahan masalah, melaksanakan rencana, meninjau kembali dengan sangat baik. 2) Siswa pada kategori sedang memiliki kemampuan untuk memahami masalah dan merencanakan pemecahan masalah yang sangat baik. Selain itu siswa kategori sedang juga memiliki kemampuan melaksanakan rencana yang cukup baik, namun memiliki kemampuan meninjau kembali yang kurang baik. 3) Siswa pada kategori rendah memiliki kemampuan untuk memahami masalah dan merencanakan masalah cukup baik, namun memiliki kemampuan merencanakan pemecahan masalah dan melaksanakan rencana yang kurang baik. Selain itu siswa pada kategori rendah tidak melakukan tahapan meninjau kembali jawaban.
\end{abstract}

Kata Kunci: kemampuan pemecahan masalah; matematika; teori polya

\section{Pendahuluan}

Matematika adalah mata pelajaran yang menggunakan bahasa simbolis dan universal dan merupakan ilmu tentang kuantitas Firmansyah \& Haris (2019:15). Salah satu tujuan pembelajaran matematika adalah mengembangkan kemampuan pemecahan masalah. Hal ini 
dikarenakan siswa akan memperoleh pengalaman dan pengetahuan serta keterampilan yang dimiliki untuk menyelesaian soal. Sehingga, ini menandakan bahwa pemecahan masalah merupakan salah satu kemampuan yang sangat penting diasah dalam pembelajaran matematika (Netriwati, 2016: 182). Pemecahan masalah matematika adalah Proses menerapkan pengetahuan matematika yang telah diperoleh sebelumnya kedalam situasi baru yang belum diketahui (Fadillah, 2018: 14). Artinya, masalah dalam matematika dapat dideskripsikan sebagai soal matematika yang strategi penyelesaiannya tidak langsung terlihat sehingga dalam penyelesaiannya memerlukan pengetahuan, keterampilan dan pemahaman yang telah dipelajari sebelumnya.

Kemampuan pemecahan masalah matematika yang digunakan dalam penelitian ini yaitu merujuk pada teori Polya. Berikut ini merupakan tahapan-tahapan yang perlu diperhatikan dalam proses penyelesaian menurut Polya: (1) siswa memahami masalah; (2) siswa menyusun rencana penyelesaian; (3) siswa melaksanakan rencana penyelesaiannya; dan (4) meninjau kembali hasil dan penyelesaian yang dibuat(Asmarani dan sholihah, 2017: 32).Hal ini bertujuan agar siswa lebih terampil dalam menyelesaikan masalah matematika, yaitu terampil dalam menjalankan strategi dalam menyelesaikan masalah secara cepat dan cermat. Menurut Saad dan Gani (2008)yang dikutip oleh Amin $(2016,3)$ menyatakan bahwa tahap pemecahan masalah menurut Polya juga digunakan secara luas di kurikulum matematika di dunia dan merupakan tahap pemecahan masalah yang jelas. Sehingga dengan kata lain, tahap Polya tepat digunakan untuk pemecahan masalah dalam matematika, tidak terkecuali matematika sekolah. Jadi dalam menyelesaikan soal pemecahan masalah siswa sebaiknya menggunakan tahap pemecahan masalah yang meliputi empat indikator kemampuan pemecahan masalah diatas.

Hasil observasi di SDN 02 Amban, diperoleh data bahawa kemampuan pemecahan masalah siswa tergolong rendah. Hal tersebut terlihat dari hasil tes kemampuan pemecahan masalah siswa kelas VI, diperoleh 62 \% siswa masih belum mencapai KKM. Hasil wawancara dengan guru kelas, diperoleh fakta bahwa siswa memang mengalami kesulitaan dalam memecahkan masalah matematika. Selain itu guru beranggapan perlu menganalisis kemampuan pemecahan masalah siswa sehingga mencari solusi alternatif pembelajaran yang mampu meningkatkan kemampuan pemecahan masalah sesuai dengan karakteristik siswa.

Berdasarkan latar belakang, Tujuan Penelitian ini yaitu untuk menetagui kemampuan pemecahan masalah matematika siswa berdasarkan teori Polya pada siswa SD kelas VI Kabupaten Manokwari. Pemecahan masalah merupakan suatu proses kompleks yang menuntut seeorang untuk mengkoordinasikan pengalaman, pengetahuan, pemahaman dan intuisi dalam rangka memenuhi tuntutan dari suatu situasi. Memecahkan masalah adalah suatu bentuk menghadapi kesulitan, dalam dunia pendidikan masalah dipandang sebagai suatu proses untuk menemukan kombinasi dari sejumlah aturan yang dapat diterapkan dalam upaya mengatasi situasi yang baru (Fadilah, 2018:24).

Teori Polya dalam (Widyastuti 2015: 190) ada 4 langkah dalam memecahkan suatu masalah yaitu:

a. Memahami masalah

Memahami suatu masalah yang harus dilakukan adalah pahami bahasa atau istilah yang digunakan dalam masalah tersebut, merumuskan apa yang diketahui, apa yang ditanyakan, apakah informasi yang diperoleh cukup, kondisi/syarat apa saja yang harus terpenuhi, 
nyatakan atau tuliskan masalah dalam bentuk yang lebih operasional sehingga mempermudah untuk dipecahkan. Kemampuan dalam menyelesaikan suatu masalah dapat diperoleh dengan sering menyelesaikan masalah.

b. Merencanakan pemecahan masalahan

Memilih rencana pemecahan masalah yang sesuai bergantung dari seberapa sering pengalaman kita menyelesaikan masalah sebelumnya. Semakin sering kita mengerjakan latihan pemecahan masalah maka pola penyelesaian masalah itu akan semakin mudah didapatkan. Untuk merencanakan pemecahan masalah kita dapat mencari kemungkinankemungkinan yang dapat terjadi atau mengingat-ingat kembali masalah yang pernah diselesaikan yang memiliki kemiripan sifat/pola dengan masalah yang akan dipecahkan.

c. Melaksanakan rencana

Langkah ini lebih mudah dari pada merencanakan pemecahan masalah, yang harus dilakukan hanyalah menjalankan strategi yang telah dibuat dengan ketekunan dan ketelitian untuk mendapatkan penyelesaian.

d. Meninjau kembali

Kegiatan dalam langkah ini adalah menganalisis dan mengevaluasi apakah strategi yang diterapkan dan hasil yang diperoleh benar, apakah ada strategi lain yang lebih efektif, apakah strategi yang dibuat dapat digunakan untuk menyelesaikan masalah sejenis, atau apakah strategi dapat dibuat generalisasinya. Ini bertujuan untuk menetapkan keyakinan dan memantapkan pengalaman untuk mencoba masalah baru yang akan datang.

\section{Metode Penelitian}

Metode penelitian yang digunakan oleh peneliti merupakan penelitian kualitatif dengan pendekatan deskriptif. Pada tahap persiapan penelitian, peneliti melakukan pengamatan dan studi pendahuluan lalu menyusun instrumen penelitian dan melakukan validasi instrumen oleh pakar. Instrumen penelitian meliputi tes soal cerita untuk melihat kemampuan pemecahan masalah matematika, alternatif penyelesaian tes, serta pedoman wawancara.

Proses pengumpulan data diawali dengan memberikan Tes Pemecahan Masalah pada siswa 3 SD yaitu SDN 02 Amban, SD Inpres 25 Fanindi dan SD Yapis 02 kabupaten manokwari. hasil tes diperiksa dan diberi skor. Data hasil tes dikelompokkan kedalam tiga kategori kelompok yaitu kelompok tinggi, kelompok sedang, dan kelompok rendah. Pengelompokkan tersebut dilakukan dengan menggunakan pedoman kriteria kemampuan pemecahan masalah dapat dilihat pada tabel berikut.

Tabel 1 Kategori Kemampuan Pemecahan Masalah

\begin{tabular}{lc}
\hline \multicolumn{1}{c}{ Kategori } & Pencapaian Kemampuan Pemecahan Masalah \\
\hline Tinggi & $\geq 75$ \\
Sedang & $55<x<75$ \\
Rendah & $\leq 55$ \\
\hline
\end{tabular}

(dimodifikasi dari Arviana, 2014: 152)

Perwakilan dari setiap kategori kelompok dipilih untuk diwawancara dengan menggunakan teknik purposive sampling. Wawancara dilakukan kepada tiga orang terpilih. Wawancara dilakukan untuk memperkuat keabsahan dari hasil tes.hasil wawancara kemudian dibandingkan dengan hasil tes. Pada kegiatan ini peneliti bertindak sebagai pewawancara. 
Setelah data hasil tes tertulis, data hasil wawancara, dan data hasil dokumentasi terkumpul maka data dianalisis untuk melihat gambaran yang terjadi dan dibuat pembahasan berdasarkan hasil tes tertulis kemampuan pemecahan masalah matematika yang didukung oleh hasil wawancara, dan dokumentasi untuk mengetahui lebih jelas tentang kemampuan pemecahan masalah matematika berdasarkan teori Polya. Data hasil tes tertulis dikoreksi untuk melihat indikator kemampuan pemecahan masalah matematika yang dicapai oleh peserta didik. Kemudian, data hasil wawancara, dan dokumentasi akan dicocokan dengan hasil tes tertulis untuk melihat kemampuan pemecahan masalah matematika berasarkan teori Polya yang sebenarnya.

Data hasil analisis akan disajikan dalam bentuk uraian singkat dan dokumentasi gambar hasil kerja pada tes tertulis. Kemudian akan ditarik kesimpulan mengenai kemampuan pemecahan masalah matematika siswa berdasarkan teori Polya. Tahap akhir dalam penelitian ini adalah pembuatan laporan hasil penelitian dan melakukan publikasi jurnal nasional terakreditasi

Data yang diperoleh dari penelitian ini merupakan data hasil tes tertulis yang diberikan kepada siswa kelas VI SDN 02 Amban, SD Inpres 25 Fanindi dan SD Yapis 02 kabupaten manokwari., hasil wawancara dan hasil dokumentasi. Pada penelitian kualitatif daeskriptif ini peneliti menggunakan prosedur analisis data model Analysis Interactive dari Miles \& Huberman (1994:12) yang membagi kegiatan analisis menjadi beberapa bagian yaitu: reduksi data, penyajian data dan penarikan kesimpulan.

\section{Hasil dan Pembahasan}

Poses penelitian diawali penyusunan instrument penelitian berupa tes kemampuan pemecahan masalah (TKPM) dan pedoman wawancara dari tanggal 7-18 Desember. Setelah proses penyusunan, instrument melui tahap validasi oleh 2 validator. Hasil validasi instrument penelitian dapat dilihat pada tabel dibawah ini

Tabel 2 Rekapitulasi Penilaian Validator terhadap Instrumen Penelitian

\begin{tabular}{llcccc}
\hline \multirow{2}{*}{ No } & Instrumen Penelitian & \multicolumn{2}{c}{$\begin{array}{c}\text { Sata-Rata } \\
\text { Skor }\end{array}$} & $\begin{array}{c}\text { Rata- } \\
\text { Validator }\end{array}$ & Kategori \\
& & V 1 & V 2 & & \\
\hline 1 & Tes Kemampuan Pemecahan Masalah & 3.67 & 3.83 & 3.75 & Sangat Baik \\
2 & Pedoman Wawancara & 3.2 & 3.8 & 3.5 & Sangat Baik \\
\hline
\end{tabular}

Berdasarkan hasil penilaian dari validator diperoleh rata-rata penilaian untuk semua instrument penelitian berada pada kategori sangat baik. Dari hasil penilaian tersebut dapat disimpulkan bahwa instrumen penelitian valid dan sudah layak digunakan dalam penelitian.

Tahap selanjutnya yaitu Proses Pengumpulan data yang telah dilakukan di 3 Sekolah Dasar di Kabupaten Manokwari yaitu SD Inpres 25 Fanindi pada hari Rabu 10 Februari 2021, SDN 02 Amban pada hari Rabu 17 Februari 2021 dan SD Yapis 02 Manokwari Selasa 23 Februari 2021. Pelaksanaan tes dilakukan selama 2 × 30 menit dengan mengikuti protokol kesehatan yan telah ditetapkan oleh masing-masing sekolah. Berdasarkan hasil tes kemampuan pemecahan masalah siswa diperoleh data sebagai berikut : 
Tabel 3 Rekapitulasi Hasil Tes Kemampuan Pemecahan Masalah

\begin{tabular}{|c|c|c|c|c|c|}
\hline \multirow[t]{2}{*}{ No } & \multirow[t]{2}{*}{ Nama Sekolah } & \multicolumn{3}{|c|}{$\begin{array}{c}\text { Kategori Kemampuan } \\
\text { Pemecahan Masalah }\end{array}$} & \multirow[t]{2}{*}{ Jumlah Siswa } \\
\hline & & $\mathbf{T}$ & $\mathrm{S}$ & $\mathbf{R}$ & \\
\hline 1 & SD Inpres 25 Fanindi & 7 & 7 & 16 & 30 \\
\hline 2 & SDN 02 Amban & 6 & 3 & 19 & 28 \\
\hline 3 & SD Yapis 02 Manokwari & 6 & 4 & 2 & 12 \\
\hline & Responden & 19 & 14 & 37 & 70 \\
\hline
\end{tabular}

Berdasarkan tabel 3 diatas diperoleh data hasil kemampuan pemecahan masalah siswa terdiri dari 19 siswa (27 \%) berada pada kategori tinggi, 14 siswa (20\%) berada pada kategori sedang dan 37 siswa (53\%) kategori rendah. Hasil kemampuan pemecahan masalah dapat dilihat lebih lengkap pada lampiran 3, 4 dan 5.

Setelah proses pemeriksaan hasil tes kemampuan pemecahan masalah, peneliti kemudian melakukan wawancara berdasarkan indicator teori Polya kepada 9 siswa yang terdiri dari 3 siswa SD Inpres Fanindi, 3 siswa SDN 02 Amban dan 3 siswa SD Yapis 02 Manokwari. Proses wawancara dilakukan di hari yang sama dengan proses tes kemampuan pemecahan masalah. Pemilihan siswa mewakili kategori tinggi, sedang dan rendah. Siswa yang terpilih sebagai berikut :

Tabel 4 Siswa yang menjadi responden pada proses wawancara

\begin{tabular}{llccc}
\hline \multirow{2}{*}{ No } & \multirow{2}{*}{ Nama Sekolah } & \multicolumn{3}{c}{$\begin{array}{c}\text { Kategori Kemampuan } \\
\text { Pemecahan Masalah }\end{array}$} \\
& & $\mathbf{T}$ & S & R \\
\hline 1 & SD Inpres 25 Fanindi & F13 & F05 & F30 \\
2 & SDN 02 Amban & A13 & A05 & A02 \\
3 & SD Yapis 02 Manokwari & Y03 & Y05 & Y06 \\
\hline
\end{tabular}

Setelah melakukan analisis data hasil penelitian, diperoleh bahwa siswa memiliki kemampuan pemecahan masalah matematika yang berbeda hal tersebut sesuai dengan pernyataan Shovia dan Ekasatya $(2016,145)$ bahwa proses pemecahan masalah matematika atau matematis merupakan salah satu kemampuan dasar yang harus dimiliki oleh siswa dan setiap siswa memiliki kemampuan pemecahan masalah yang berbeda. Hal ini dapat diketahui dari hasil pengerjaan soal tes kemampuan pemecahan maslah oleh siswa ditinjau berdasarkan teori Polya.

\section{a. Memahami Masalah}

Berdasarkan hasil tes kemampuan pemecahan masalah dan wawancara diperoleh informasi bahwa siswa-siswa pada kategori tinggi dan sedang memiliki kemampuan memahami masalah yang sangat baik disetiap butir soal yang diberikan. Sedangkan siswasiswa pada kategori rendah juga mampu memahami masalah dengan baik pada butir soal 1,2 dan 4. Pada kategori rendah, A02 mengalami ketidak mampuan memahami masalah pada butir soal nomor 3 dan 5 


\section{b. Merencanakan Pemecahan Masalah}

Pada tahap ini siswa pada kategori tinggi mampu merencanakan pemecahan masalah dengan sangat baik di setiap butir soal. Siswa kategori sedang juga mampu merencanakan pemecahan masalah dengan sangat baik kecuali Y05 pada butir soal nomor 5. Siswa-siswa pada kategori rendah hanya Y06 yang mampu merencanakan pemecahan masalah. Pada tahap ini ketidakmampuan merencanakan pemecahan masalah terjadi pada F30 pada butir soal nomor 2, 4 dan 5 sedangkan A02 pada butir soal nomor 2,3,4 dan 5.

\section{c. Melaksanakan Rencana}

Tahap melaksanakan rencana dapat dilakukan dengan baik oleh semua Siswa kategori tinggi disetiap butir soal. Pada kategori sedang, Siswa mengalami ketidakmampuan melaksanakan rencana. F05 tidak mampu melaksanakan rencana pada butir soal nomor 2, dan 3. A05 tidak mampu melaksanakan recana pada butir soal nomor 2 dan 3. Y05 tidak mampu melaksanakan rencana pada butir soal nomor 2 dan 5. Sedangkan siswa kategori rendah tidak mampu melaksanakan rencana kecuali A02 pada butir nomor 1 serta $Y 6$ pada butir no mor 1 dan 4.

\section{d. Meninjau Kembali}

Secara umum siswa kategori tinggi mampu meninjau kembali jawaban yang telah mereka kerjakan dengan sangat baik pada setiap butir soal kecuali A13 pada butir soal nomor 3 dan F13 pada butir soal nomor 5. Siswa kategori rendah yang melakukan peninjauan kembali terdapat dua siswa yaitu Y05 pada butir soal nomor 4 dan 5 serta F05 pada butir soal nomor 4 . Seadangkan siswa-siswa pada kategori rendah tidak melakukan tahap meninjau kembali pada setiap butir soal

\section{Kesimpulan}

Berdasarkan analisis kemampuan pemecahan masalah matematika berdasarkan teori Polya pada siswa kelas VI yang dilakukan di SD Inpres 25 Fanindi, SDN 02 Amban dan SD Yapis 02 kabupaten manokwari dapat disimpulkan bahwa Siswa pada kategori tinggi memiliki kemampuan untuk memahami masalah, merencanakan pemecahan masalah, melaksanakan rencana, meninjau kembali dengan sangat baik. Siswa pada kategori sedang memiliki kemampuan untuk memahami masalah dan merencanakan pemecahan masalah yang sangat baik. Selain itu siswa kategori sedang juga memiliki kemampuan melaksanakan rencana yang cukup baik, namun memiliki kemampuan meninjau kembali yang kurang baik. Sedangkan siswa pada kategori rendah memiliki kemampuan untuk memahami masalah dan merencanakan masalah cukup baik, namun memiliki kemampuan merencanakan pemecahan masalah dan melaksanakan rencana yang kurang baik. Selain itu siswa pada kategori rendah tidak melakukan tahapan meninjau kembali jawaban.

\section{Daftar Pustaka}

Amin, F. (2016). Analisis kemampuan Pemecahan Masalah Siswa Kelas VIII Materi Aljabar Dengan StrategiPolya Dalam PBL Pendekatan Scientific. Skripsi, Universitas Negeri Semarang:

Arviana, N. N. (2014). Penerapan Pendekatan Differentiated Instruction Untuk Mengembangkan Kemampuan Pemecahan masalah Matematika Siwa Kelas VIII SMP Pada Materi Kubus dan Balok. Jurnal Ilmiah Pendidikan Matematika. 3(3), : 150-157. 
Asmarani, D. \& Sholihah, U. (2017). Metakognisi Mahasiswa Tadris Matematika. Tulungagung: Akademia Pustaka.

Fadilah, N., (2018). Analisis Kemampuan Pemecahan Masalah Siswa Pada Materi Persamaan Linear Dengan Strategi Pembelajaran Berbasis Masalah Kelas X MAN 5 T.P. 2017/2018". Skripsi. Medan: UIN Sumatera Utara.

Firmansyah \& Haris. (2019). Pengembangan Bahan Ajar Matematika SD Bernuansa Ethnomatematika Masyarakat di Bumi Hibualamo. Jurnal Hibualamo Seri Ilmu-ilmu social dan kependidikan Vol 3 (2)

Heruman. (2008). Model Pembelajaran Matematika di Sekolah Dasar. Bandung: Rosda Karya

Lestari, K.E. dan Yudhanegara, M.R. (2015) Penelitian Pendidikan Matematika. Bandung : PT Refika Aditama.

Miles, M. B., \& Huberman, M. A. (1994). Qualitative data analysis; an expanded sourcebook (2rd ed) London: Sage Publication

Netriwati. (2016)Analisis Kemampuan Pemecahan Masalah Matematis Berdasarkan Teori Polya Ditinjau dari Pengetahuan Awal Mahasiswa IAIN Raden Intan Lampung". Jurnal Pendidikan Matematika. 7(2), 181-190.

Raharjo, Marsudi, Dkk. (2009). Pembelajaran Operasi Hitung Perkalian dan Pembagian Bilangan Cacah di SD. Pusat Pengembangan dan Pemberdayaan Pendidik dan Tenaga Kependidikan (PPPPTK) Matematika : Jakarta

Rusmining, Waluya, S. B., dan Sugianto. (2014). Analysis of Mathematics Literacy, Learning, Learning Constructivism Character and Education (Case Studies on IX Class of SMK Roudlotus Saidiyyah Semarang Indonesia). International Journal of Education and Research, 2(8): 331-340.

Shovia, Ekasatya. (2016). Kemampuan Pemecahan Masalah Siswa ditinjau Melalui Model Pembelajaran SAVI dan konvensional. Jurnal pendidikan. 2(2), 142-152

Wardhani, S., \& Rumiati. (2011). Modul Matematika SMP Program Bermutu Instrumen Penilaian Hasil Belajar Matematika SMP: Belajar dari PISA dan TIMSS. Jakarta: Kemendiknas dan PPPPTK.

Widyastuti, Rany. (2015). Proses Berpikir Siswa Dalam Menyelesaikan Masalah Matematika Berdasarkan Teori Polya Ditinjau Dari Adversity Quotient Tipe Climber. Jurnal Pendidikan Matematika, 6 (2), 183-193. 